\title{
A Visit to the Vancouver Public Library
}

By Donna Wells

Probably many librarians like myself enjoy seeing the public library of any city in which they are visiting. Some of the buildings are massive marble edifices that have stood for many years, like the Library of Congress. Some are architecturally bold and nearly unrecognizable as a library, like the Seattle Public Library, which looks like a giant glass cube balanced on one corner. The exterior the Vancouver Public Library (VPL) has a striking and familiar style. It looks like a modern replica of the Roman Coliseum with modern glass windows, different stone, in better shape, and a less checkered past.

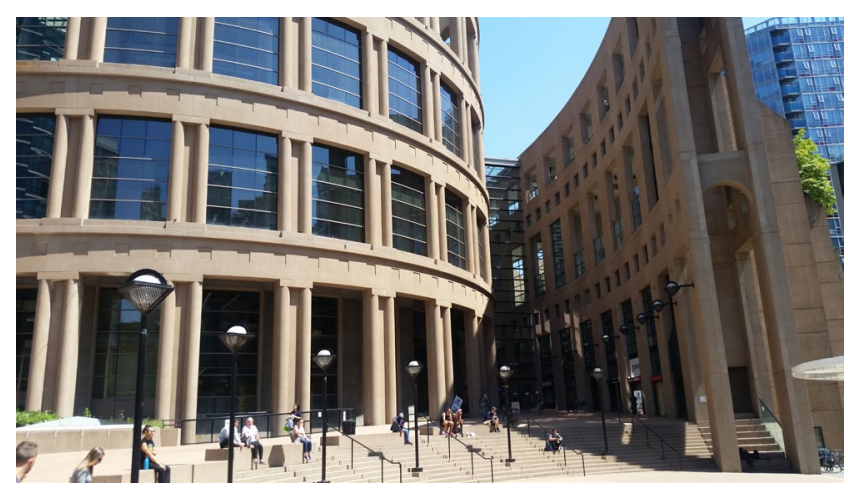

Exterior view of VPL. Photo credit: Leslie Engelson

Four other Atla members and I went to visit the library after the conference luncheon on Saturday, June $15^{\text {th }}$. It is located at 350 West Georgia Street and was just a short walk from the hotel. When we saw it we agreed the structure was as impressive as we had been told. Our conference speaker from the library, Alex MacCutchan, Manager of Information, told me the library itself is a rectangular building. It is surrounded by a free-standing circular structure which is accessed by bridges. It is a sight to see, large and eye-catching. This branch of the VPL employs over 700 people.

The library's main entrance opens into a soaring glass-ceilinged atrium with colorful awnings inviting you into various eating establishments on the one side. (Food and drink are welcome inside the library.) On the other are the glass walls of the impressive nine-story library. A 21-story office tower is an extension of the east side of the circular wall. After gawking at all this grandeur, the inside of the library itself is of a standard type-circulation and information desks, stacks and stacks of books, and various tables and chairs. Nice, but not extraordinary.

However, the library has been working, and continues to work, toward being an open and inviting and inclusive space for all people. The library has relabeled their restrooms as "Trans Welcome" and have created and implemented staff training on the use of gender-neutral language and behavior. Alex explained they have also been sensitive to the Two-Spirit people, a First Nations term for a body that contains the spirit of both male and female. We saw signs (literal and figurative) of this initiative on

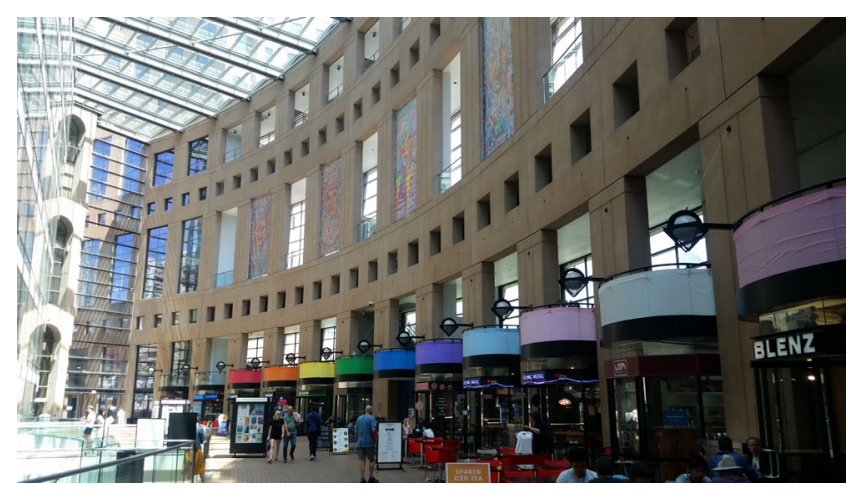

Inside main entrance of VPL. Photo credit: Leslie Engelson.

Donna Wells is Associate Director and Head of Technical Services at Southeastern Baptist Theological Seminary. She currently serves as the Atla liaison to the CC:DA. 
our tour of the library. You can read more about this initiative and read the signage in this article from $\underline{\text { The }}$ Georgia Straight.

The building was finished in 1995 and although it has nine floors, up until 2016 the library occupied only the first seven. Floors eight and nine were given over as government offices and the roof was supposed to have a garden, but was planted as a 'green roof' instead, with plants covering 20,000 square feet of the 28,000 square-foot roof. The vegetation consisted of native grasses and trees. The purpose of the green roof was to help with water retention and runoff, regulating the temperature in the building, improving the city's air quality, and providing a habitat for birds, bees, and butterflies. It was not open to the public. Around 2016 the lease on the top two floors of the building expired and the library was able to claim that space as its own; a complete renovation was undertaken. A problem occurred because these top floors were not reinforced to handle the heavy load of book stacks. Instead, the extra square footage was converted for public use areas. Besides the exterior, this is where the VPL really stands out. The renovation included a glass-enclosed reading room, individual meeting rooms, an 80-seat theater, and an exhibition space, all open and airy and modern. The crown jewel however is considered to be the rooftop gardens. There are two terraces on the eighth floor, 4,700 square feet

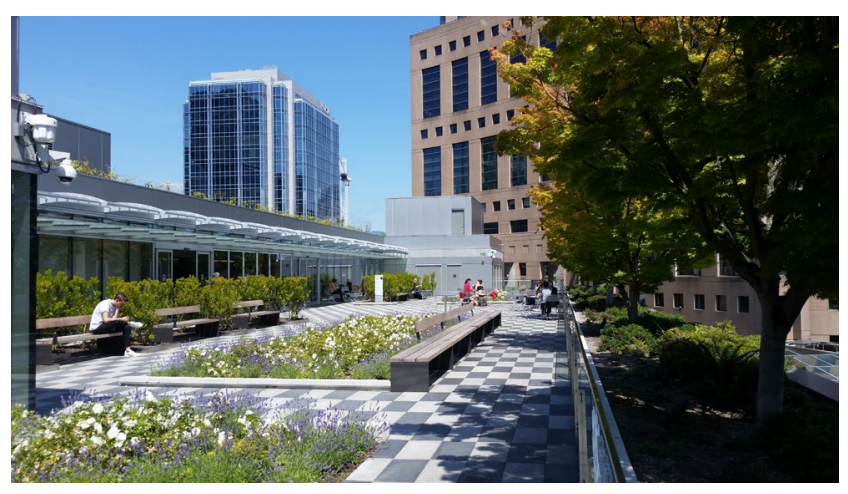

Rooftop terrace and garden at VPL. Photo credit: Leslie Engelson each, and two on the ninth totaling 7,400 square feet. The green roof was retained in smaller square footage around the perimeter of the building and is supplemented by various flowering perennials and trees, tables, chairs, and spectacular views of the city of Vancouver. The top two floors opened to the public in September, 2018.

It was a very fun and encouraging excursion. Seeing a lively, thriving, and beautiful library brings me great joy. If you have not already, put stopping at a city's library on your must-see list for any place you visit. 